ÉGYPTE

monde arabe

\section{Égypte/Monde arabe}

4 | 2007

Figures de la santé en Égypte

\title{
Public Health in Crete under the rule of Mehmed
}

Ali in the 1830's

\section{Panagiotis Krokidas and Athanasios Gekas}

\section{(2) OpenEdition \\ Journals}

Electronic version

URL: https://journals.openedition.org/ema/1751

DOI: $10.4000 /$ ema. 1751

ISSN: 2090-7273

\section{Publisher}

CEDEJ - Centre d'études et de documentation économiques juridiques et sociales

\section{Printed version}

Date of publication: 31 December 2007

Number of pages: $35-54$

ISBN: 2-6905838-43-4

ISSN: 1110-5097

Electronic reference

Panagiotis Krokidas and Athanasios Gekas, "Public Health in Crete under the rule of Mehmed Ali in the 1830's", Égypte/Monde arabe [Online], 4 | 2007, Online since 31 December 2008, connection on 07 July 2022. URL: http://journals.openedition.org/ema/1751 ; DOI: https://doi.org/10.4000/ema.1751 


\title{
Panagiotis Krokidas \& Athanasios (Sakis) GeKas
}

\section{PUBLIC HEALTH IN CRETE UNDER THE RULE OF MEHMED ALI IN THE 1830S}

\begin{abstract}
$W^{\prime}$ hen the last bastion of Venetian dominion in Crete, Candia, fell in 1669, the island passed under Ottoman rule. During the Ottoman period, Crete's population was clearly stratified between subordinate Christians and ruling Muslims and many Christians converted to Islam in order to maintain land and privileges, fiscal as well as social that came with Muslim status. The presence of a strong local administration, the army of janissaries, the poverty of the rural, predominantly Christian, as opposed to the urban Muslim, population and the abuse of the former by the 'Turkish' authorities were among the main images conveyed by an Austrian traveller and physician, F. Sieber, in his account from his one-year stay in Crete in 1817. In 1821, many Christians in Crete joined in the Greek War of Independence. The island came under the rule of Mehmed Ali for the first time in 1822 when 7,000 soldiers landed on the island and were ordered to suppress the Christian insurgency. In 1830, the Allied Powers having allowed the establishment of an independent Greek Kingdom decided that Crete would be ruled by the government of Mehmed Ali, effectively a recognition of the Viceroy's increasing power. This decision practically saved the Muslims of Crete who had been confined to the fortified walls of the towns and would have perished or been forced to leave. ${ }^{2}$ Mehmed Ali soon discerned the economic and strategic advantages of the island. Crete became part of Mehmed Ali's expansionist plans that included the 'dream' of expansion to Sudan in the 1820s and the military campaign in Syria and other Arab provinces that were integrated into Mehmed Ali's control in the 1830s.
\end{abstract}

1. Sieber, F.W., Travels in the island of Crete, in the year 1817, London 1823 (Greek translation, Athens: Istoritis, 1994). Sieber and nineteenth-century writers in general use ethnoreligious categories such as 'Turkish' to denote the Muslim population. These categories, of course, have acquired a different meaning following the establishment of nation-states.

2. Robert Pashley, Travels in Crete, Vol. 1, Cambridge \& London: John Murray, 1837, p. xxii. 
The Viceroy of Egypt ruled Crete from 1830 until 1840. Since its early days, the Egyptian administration attempted to implement in Crete a programme of modernising reforms similar to the one that was already under way in Egypt. One of these reforms was the publication of an official newspaper, the Vekayi$i$ Giridiye, the first bilingual newspaper published in the Ottoman Empire in Ottoman and Greek languages. The newspaper followed the publication of the Vekayi-i Misriye in Cairo. The Vekayi-i Giridiye was effectively one of the first newspapers published in the Ottoman Empire and it is a source previously ignored or unknown by historians. This paper uses the newspaper in order to examine the attempts of the Egyptian administration to reform public health by organising a health system that catered for the army's and the administration's needs as well as aiming at protecting the local population from disease. It is argued that the attempt to reform public health on the island was part of a wider project to transfer to Crete a modernising model that was being established in Egypt at the time. Other attempted reforms included political equality between Christians and Muslims, administrative reform of the island and the carrying out of a number of public works. These reforms aimed at maintaining a healthy army but also benefiting the local population and thus providing legitimacy for an autocratic albeit 'benevolent' administration.

The paper, apart from presenting this previously unemployed and by and large unknown source, contributes to studies on the history of Crete during the era of the meteoric rise of Mehmed Ali, an unexplored theme of Ottoman, Egyptian and Greek history. The fact that historians have paid little attention to Crete under Egyptian rule means that the decade 1830-1840 constitutes a historical terra incognita; our aim, however, is not only to provide a narrative of the events related to attempts by the Egyptian administration to reform and organise a public health system. Identifying the basic steps towards building public health infrastructure is the means to examine a range of issues concerning the reform and modernisation programme that the administration attempted to transfer to Crete, part of which was an early attempt to establish a system of public health. Issues of public health and the reforms introduced are of primary importance since they constitute an epitome of a state's willingness to modernise. Therefore it is not surprising that the 'enlightened' and 'benevolent' Egyptian administration took up the task of pursuing these reforms.

The newspaper issues we examined were published between $9^{\text {th }}$ June, 1832 and $6^{\text {th }}$ January, $1834 .^{3}$ The newspaper was published in four pages in the Government printing office of Chania (Taba'at fi matba't divan I'vekayi-i giridiye be Hanya). This one-and-a-half year period can hardly account for the

3. Most of the Vekayi-i Giridiye issues can be found in the rare books collection (Eski ve Nadir Eserler Kütüphanesi) of Istanbul University, while fifteen issues of Vekayi-i Giridiye or Vekayi-i Girit (as it is also known) can be found in Greece, in the Crete Records Office in Chania as well as in the Eraklio History Museum (only one issue). 
whole period of Egyptian rule in Crete; nevertheless, it was during those first few years that the regime's foundations were laid. The social policy and health reforms in particular introduced during the period can provide a useful benchmark for assessing the overall impact of Mehmed Ali's rule in Crete.

\section{CRETE UNDER THE RULE OF MEHMED ALI}

The public health reforms and organization efforts implemented in Crete during this period cannot be examined in isolation; instead they should be analysed in the context of the broader principles of Egyptian policy and rule, and the administration's strategy to promote welfare for both the Christian and the Muslim populations, in an attempt to return the island to a condition of 'equilibrium' between the two communities. This balance had been upset during the 1820s and the years of fighting between Christian and Muslim Cretans and, after 1822, between Christian insurgents and the Egyptian army. This is not to say though that in pre-revolutionary times conditions between Christians and Muslims had been equal; Christians in the Ottoman Empire until the Tanzîmât reforms were second-class citizens and, if we believe travellers' accounts about Crete, Christians suffered under particularly harsh treatment by some Muslims.

A number of welfare policies were devised after the end of the war in 1830, which included giving confiscated land back to Christian families that had fled to the mainland during the war, building schools for both communities and restoring oil presses regardless of the religion of the owner. ${ }^{4}$ Pashley estimated that the number of those who fled the island during the 1820 s probably exceeded 30,000. ${ }^{5}$ A number of other issues were settled by the new administration, such as the quantity of the water consumed and compensation to farm owners for damages of livestock. All those resolutions were propagated in the newspaper and what is striking is the concept of law and order that appears to drive changes in the island's society and thus promoting welfare for its people, regardless of religion. By reading the official newspaper alone one gets the impression that this was actually a well-governed state, treating its Christian and Muslim population equally; referring to contemporary sources other than the Vekayi-i Giridiye, however, presents a slightly different picture.

Mehmed Ali appointed in Crete Mustafa Pasha, an entrusted native of Cavalla like the Viceroy himself, because of his experience and acquaintance with "European usages". ${ }^{6}$ Pashley, British traveller and scholar, who met the Pasha in 1837, had only words of praise for him, stressing that he had become acquainted with the Greek language since his appointment in the island. The

4. Vekayi-i Giridiye (hereafter VG), No. 68, 12 August, 1832.

5. Pashley, xxiv.

6. Pashley, Vol. I, p. 173. 
form of community organization instituted by the authorities dictated that each village had two leaders, one Christian one Muslim, and that Christian villages were supervised by Christian notables only. The first decrees of Mehmed Ali were promising indeed. Pashley recorded that the Viceroy "did all he could to appease the terror and to inspire confidence in his government" to the people who returned from exile. Within a few months, all hostilities had ended and Egyptian rule returned the island to a situation of law and order that had not been seen since Venetian times, or so Pashley recorded. ${ }^{7}$ Essential in this series of measures was equality before the law and participation of both religious communities in the administration of the island. Two councils were established, one at Megalo Kastro (Eraklio) and the other at Chania; councils consisted of members of both religions and were responsible for administration and for delivering justice in cases. These measures during the first months of the administration were accompanied by concrete promises for improvement of the Christians' social status; Pashley notes that the Governor-general, Mustafa Pasha Osman Bey, issued a proclamation to the Christians of the island, who had already given up their arms, telling them "that the sole object of their Master, Mehmet Ali Pasha, was to establish the tranquillity and to cause the prosperity of Crete, and to deliver the Christians from the vexations to which they were formerly exposed." ${ }^{8}$

All this was to change relatively quickly however, when in October 1831, the period of good government came to an end. Pashley thinks Mehmed Ali aimed at converting the island into a source of revenue and to this end ordered heavy taxation and strict law-enforcing punishments for everyone who broke the law. A tough policy on law and order involved floggings of soldiers who misbehaved; such news appear frequently in the pages of the Vekayi-i Giridiye and Pashley, writing on the Egyptian policy on the island, noted that Mehmed Ali thought he could govern the island like one of his African dominions, ignoring the "difference of character between the warlike mountaineer of Crete and the miserable fellah of Egypt," and at the end neutralizing the municipal councils by terrorizing with exile members who went against the sovereign's will. ${ }^{9}$

It is interesting to note that authoritative rule was directed towards Christians as well as Muslims. Pashley notes that the power of the "higher classes of the Mohammedans" was curtailed, while Christians could only complain of heavy taxation. ${ }^{10}$ The complaints against heavy taxation were reiterated throughout Pashley's journey to Crete and in 1837, he argued that "at last the villagers begin to unburden themselves of their grievances: to speak to me of the proceedings of the government: of the merciless changes in the system of taxation:

\footnotetext{
7. Ibid.

8. Pashley, xxv.

9. Pashley, xxvi.

10. Pashley, xxix.
} 
of the duties on the leather for their boots, of the piaster for each mistato of their wine and of the various other extortions, which, they say, make them all, Christians and Mohammedans, long for the Frank, that is for some European power, instead of the Egyptians."11 Still, there were improvements in the equality of the two communities before the administration, even if sometimes this felt more like equality in fear of the authorities: "The reaya walks more erect and lives in a less horrible and wretched state of fear and trembling under Mehmet Ali than in any part of what may still be called the Sultan's dominions. Here the Cretan Mohammedan fears the established authorities as much as the Christian does: while, under the Sultan, the Muslim is an insolent tyrant, and the Greek a wretched slave."12 Could these be the distorted conclusions of a patronizing British towards Egyptian rule in Crete? One way to answer the question is by looking at the changes in public health implemented during the period of Egyptian rule, albeit through the publication of its official newspaper.

\section{POLICY AND PUBLIC HEALTH BEFORE AND DURING EGYPTIAN RULE}

Public health conditions in the years before the advent of Egyptian rule are described by Sieber, an Austrian doctor and botanist. In his account of Crete in 1817, Sieber portrayed the distinct lack of medical care for the vast majority of the population and the presence of very few doctors in the towns of the islands. This monopoly occasionally led to medical 'scandals': the abuse of professional position and power by doctors for profit and their ignorance of even the basic symptoms of illness. Sieber scorned local doctors, saying that they were equally unable to diagnose the condition of patients, let alone suggest the right treatment with botanical substances they used for preparing drugs. Sieber noticed emphatically the arbitrary, occasionally incompetent and exploitative attitude of an Italian by the name of Domenico, the doctor appointed by the Pasha in Candia (Eraklio). Disease, the most severe of which was plague but also smallpox, was rampant and recurring not only in the countryside but also in the town of Chania; the Austrian doctor narrowly escaped being contaminated by the plague in one of his visits to the town in 1817. In Chania, he also met another doctor, Renieri, an encounter that gave him the chance to reflect on local medical practices (or rather, the lack thereof) and be critical of them. A number of other illnesses were also registered by Sieber, who was astounded by the disregard for hygiene and the complete lack of hospitals, which aggravated poor health and decimated the local population. Occasionally, Sieber went on to generalise about health conditions in the 'Levant' based on his experiences from Crete: "In the Levant, where there is no policing on doctors, the situation

11. Pashley, Vol II, p. 130.

12. Pashley, Vol. II, p. 80. 
is terrible." 13 The account provided by Sieber is not only interesting in itself for describing the experience of a 'European' traveller, professional physician and interested botanist in Ottoman Crete; it is - more importantly for this paper - useful as a background to the changes introduced by the Egyptian administration in an attempt to modernise living conditions in general and public health in particular, aiming to cure precisely the ills identified by Sieber fifteen years earlier.

The organization of the health system in Crete was part of the modernization programme and health reform pursued in Egypt by Mehmed Ali. His project to achieve provision of health services both in towns and in the countryside was pioneered in Egypt with the assistance of Dr. A.B. Clot, when in 1827, the first western-style teaching hospital and medical school was established in Egypt. ${ }^{14}$ While no similar institution was founded in Crete, the reforms pushed through during the decade 1830-40 allow us to infer that the changes introduced bear the marks of the health reform programme already underway in Egypt. ${ }^{15}$ It was Mehmed Ali's belief in the necessity to maintain a healthy army in particular that drove the successfully implemented programme of establishing Egyptian power in Crete and directed the organisation of sanitary stations and the health system in the island during the 1830s. Like every other modern nineteenthcentury state, the Egyptian authorities in Crete attributed particular importance to the health conditions of the army.

The public health reform programme instituted in Crete was supervised by Caporal, probably a French doctor in a role similar to Dr. Clot's in Egypt. Numerous Italian and French physicians and pharmacists were already employed in the Egyptian military, and also served as teaching staff for Clot's medical school when it opened in $1827 .{ }^{16}$ Those of Italian origin and education had served as doctors in Crete for long. Sanitary stations and lazarettos (lazaretolar), dispensaries (eczaneler) and hospitals (ispedaliye) were constructed and funds were allocated quite generously. Egyptian authorities granted pensions to some soldiers with medical problems, who had served in the army in Egypt and decided to retire in Crete due to old age, receiving a few kuruş per week. The measure aimed also, perhaps, at preventing vagrancy and protecting the aesthetic of the town. On the occasion of Mehmed Ali's visit to Crete in summer 1833, the authorities embarked on an ambitious programme of social reform. This involved registering the wealthy and poor of the island, a task

\section{Sieber, p. 176.}

14. Sheldon Watts, 1997, Epidemics and History. Disease, Power and Imperialism, New Haven \& London: Yale University Press, p. 37.

15. Moulin, Anne Marie, 2002 "L'esprit et la lettre de la modernité égyptienne. L'enseignement médical de Clot bey », Cahier des Annales islamologiques, 22, pp.119-134.

16. Kuhnke, LaVerne, 1990, Lives at risk: public health in nineteenth-century Egypt, Berkeley: University of California Press, p. 35. 
assigned to enumerators with the help of community leaders, and finding ways for the rich to help the poor. The proclamation stipulated however that the poor should help themselves by cultivating land that had remained idle. Prostitutes were obliged to live and work in a special district near the port of Chania (fahişe mahallesi) and a series of measures for public health was imposed on the island. Last but not least, as the newspaper proudly announced, Mehmed Ali himself ordered the cowpox vaccine (vaçina) to be brought from France and provided to both Muslim and Christian children for free. In the rest of the paper these reforms are examined in detail.

Proclamations of this kind in the state newspaper were far from being a rare event. In fact, the discourse and political position expressed by the Vekayi-i Giridiye served as an advocate of Mehmed Ali's reforms in the islands, aiming to gain western credentials of a 'modern' administration. The issue became particularly pressing when in 1833 Athens newspapers called the ruler of Crete a tyrant. In order to refute these claims, a Vekayi-i Giridiye article listed the achievements of Egyptian rule in the first few years, including the establishment of sanitary stations and the introduction of vaccination from Europe, "in order to vaccinate for free the children of the poor."17 Clearly, the health measures taken since the first years of Egyptian rule were an achievement the authorities were proud of and advertised accordingly.

Sanitary measures in Crete, as everywhere, required the construction of the necessary infrastructure and the Egyptian administration provided the funds for these works. Lazarettos were founded and manned by qualified doctors, who were appointed by the local councils. Sanitary stations were built and equipped and their function was complemented by efficient administration. ${ }^{18}$ All sanitary stations had to account for incomes and expenses, thus reducing, if not eliminating, the possibility of corruption and fraud. These stations were also properly manned with guards who received payment in cash and food. In total, seven sanitary and quarantine stations operated in the island in Hanya, Kandiye, Resmo, spralonga, Kastel, Suda and sfakiye, that is in present-day Chania, Eraklio, Rethymno, Spinalonga, Castelli, Souda and Sfakia. On some occasions, the authorities also paid for the provision of bread to the poorest who were restricted and could be under quarantine for up to 21 days, depending on the origin of their ship. ${ }^{19}$ The Chania 'General Health Office' was the main one and was responsible for supervising all other stations in the island. ${ }^{20}$

In 1832, the Chief Medical Inspector summoned the heads of the two religious communities and the chief architect of the town in Eraklio and consulted them on the extension of the hospital for the regular army. Funds were allocated

17. VG, No. 104, 11 August, 1833.

18. VG, No. 60, 9 June, 1832.

19. VG, No. 62, 28 June, 1832.

20. VG, No. 16, 25 April, 1831. 
quite generously, especially for works so important to public health. The construction of a sanitary station in the port of Eraklio cost 10,717 kuruş, according to the report of the head of the Customs Office and Chief of the Crete Sanitary Committee. In 1832, the monthly salary of the officers in the sanitary station in Chania and Suda was 150 kuruş. ${ }^{21}$ These were some of the highest salaries of public officials. During the same year, the Council of Chania ordered the imams to notify immediately the Council and health officers when a Muslim died in order to take all necessary health measures. Respectively, the Bishop of Kydonia and Kissamos, as well as the Chief Rabbi, ordered to be notified immediately of the deaths of Christians and Jews. ${ }^{22} 1832$ was a particularly good year for public health as the military hospital in Chania was renovated at the cost of nearly 6,000 kuruş. ${ }^{23}$ A few months later, 150 mattresses and 75 beds were ordered for the Chania military hospital when a regiment of the Egyptian Army arrived there. ${ }^{24}$ The detail of information concerning public health was published in the state newspaper in order to provide a public account of public finances, in conformity with the workings and obligations of a 'modern' administration.

The lazarettos and sanitary stations were a source of state revenue as well. In one month, the sanitary station of Eraklio collected in total 2,658 kuruş from authorizing bills of health for passengers and goods, while its expenses amounted to $706 .{ }^{25}$ It is clear from the newspaper that the accounts of each sanitary station were thoroughly checked by the Viceroyal council of Eraklio (in the above case) and approved. It is interesting to note that the account books were kept in double, with a copy being sent monthly to the central authorities, demonstrating the efficient and 'scientific' way of administering financial matters related to health. The submitted reports included the logistics, expenses for equipment and construction of the new hospital, which was designed to have 1,200 beds. The total cost amounted to 3,288 kuruş; the production of nails for building the hospital was assigned to local smiths - an attempt to promote domestic craftsmanship and save money at the same time. Another interesting information in the list of expenses concerns daily wages for carpenters and masons: 4 kuruş each. ${ }^{26}$

In Egypt, the first two military hospitals were established under Dr Clot's directions in Cairo and Alexandria in 1827. Military hospitals in Crete most likely followed the same medical practices as the ones in Egypt. In late 1833, the accounts for the new sanitary station and lazaretto built in Eraklio were inspected by $\mathrm{Hacı}$ Mehmed Ağa, former Customs and Medical Officer and

21. VG, No. 60, 9 June, 1832.

22. VG, No. 68, 12 August, 1832.

23. VG, No. 65, 22 July, 1832.

24. VG, No. 114, 9 November, 1833.

25. VG, No. 85, 24 January, 1833.

26. VG, No. 92, 12 April, 1833. 
Vice-president of the Health Department and Sanitary Commission of the island. ${ }^{27}$ The relationship between military medicine and the diffusion of health measures to the rest of the population is a pattern that was followed in Crete as well as in Egypt. Egyptian officials, appointed in Crete, facilitated the organization in charge of the army's health needs. A model medical facility was deemed to be capable of accommodating 400-900 patients and the military hospital in Cairo, after its expansion, contained 1,200-1,600 beds. ${ }^{28}$ Thus, the proclamation on the construction of 1,200 beds for the hospital in Crete, if realised, must have provided a hospital equivalent to those in Egypt at the time. The needs of the army hospitals intensified when, in November 1833, a new regiment arrived from Egypt. ${ }^{29}$ It is evident that the needs of the army, especially its medical needs, were among the authorities' highest priorities.

The public health modernization project would have been incomplete if it had neglected cleaning the streets in the towns from human and animal waste. What is most interesting is the justification provided for the necessity to keep streets and markets clean, especially during the summer months when the smell must have been particularly unpleasant. This was not to be found anywhere else than in the Quran and the words of the Prophet who said: "Religion hangs from Cleanness". ${ }^{30}$ Equally interesting is the segregation of prostitution in a controlled zone near the port of Chania; in September 1832, on the occasion of a street fight between residents and guests in a hotel, several prostitutes were found to be entertaining some guests. They were subsequently punished by imprisonment for 'operating' in a part of town where 'honest people live', that is, outside the designated prostitution-area of the town and the rowdy guests were flogged - the usual punishment at the time. ${ }^{31}$ In the context of Law and Order which the Egyptian authorities wanted to impose, a disorderly society could not be tolerated and prostitution had to be controlled for health as well as propriety purposes.

The Egyptian authorities did not spare resources for the proper functioning of the administration. Funds for equipment, foodstuff and, of course, wages for doctors, pharmacists and military trainers were allocated. All staff in the Eraklio hospital was European and their wages, by September 1833, amounted to 19,000 kuruş, which the Council of Eraklio decided it had to pay after the recommendation of the regiment commander, Osman Bey. ${ }^{32}$ Also, equipment

27. VG, No. 117, 9 December, 1833.

28. Kuhnke, p. 136.

29. VG, No. 114, 9 November, 1833.

30. VG, No. 23, 24 June, 1831.

31. VG, No. 73, 22 September, 1832.

32. VG, No. 113, 2 November, 1833. Pashley had only words of praise for him, following the judgement of the French Consul, Godebot, who thought Osman Bey was "the most intelligent person in the whole island", perhaps because he could converse with him in French; Pashley (1837: 173). 
was bought and the authorities made sure that the medical needs in the hospital and other expenses were properly covered. ${ }^{33}$

Yet, the actual provision of medical care by doctors does not appear to have changed dramatically since the time when Sieber visited Crete. By 1833, doctors were appointed and were under the control of the Board of Health but this did not mean that their power diminished whatsoever. Bruzik, doctor of the Health Office in Chania and Souda asked for 270 kuruş from the Council for medical expenses and visits to Stefanos Synnefas from Chios (Sakız adası), an employee sent from Egypt to supervise the cultivation of olive groves; when the unfortunate employee fell ill and died, Bruzik saw it appropriate to claim the expenses from the Council, since the deceased was an employee paid by the Viceroy. The Council decided favourably for the doctor and paid what seems to have been a very high cost for medical expenses, a sum that ordinary folk, whether Christian or Muslim, would have found very difficult to cover in times of ill health. ${ }^{34}$ High costs were charged partly because there was not really a 'market' for medical services in Crete. Physicians in the service of Egyptians were earning a lot less than Europeans and entered the army at a lower rank; a European assistant medical officer received 350 kuruş a month, while an Egyptian received merely 150 kuruş. ${ }^{35}$ According to Clot's directives, no trained Egyptian doctors acquired the title Doctor; they were called officiers de santé instead, with or without a military rank. ${ }^{36}$ The same practice must have been followed in Crete. Whether any graduates from Clot's medical school in Egypt were dispatched and appointed to Crete remains unknown but very likely.

\section{TARGETING HEALTH HAZARDS: QUARANTINE AND PLAGUE}

Smallpox and plague were among the most frequent of communicable diseases in Crete; given that armies have 'traditionally' been the 'best' place for transmission, it was logical to undertake there measures against the spread of the disease. In early nineteenth-century Egypt, a clash occurred between the two traditional views, the ontological and the physiological concepts of the disease. This occurred when measures for protection against plague and cholera were introduced through a system of maritime quarantine similar to the European one. ${ }^{37}$ The 1820 s and 1830s were a period of experimentation for Europe, as well as for areas like Egypt, which 'imported' European practices on disease control. Bowring, the British Council stationed in Egypt in the 1830s, noted:

33. VG, No. 113, 2 November, 1833

34. VG, No. 96, 30 May, 1833.

35. Kuhnke, 38.

36. Kuhnke, 40.

37. Kuhnke, pp. 1-2. 
The introduction of the sanitary code of Europe into Egypt has not prevented the annual visitations of the plague, nor checked its fearful ravages when it has assumed the epidemical form as in the years 1834-35. The necessity of important modifications in the existing system is now strongly and increasingly felt in Egypt on the one hand, whilst on the other, the hope that the introduction of quarantine would lead to the subjugation and extirpation of the plague has been gradually fading away under the evidence of irresistible facts..$^{38}$

These opinions, of course, aimed ultimately at relaxing quarantine regulations that inhibited the mobility of people and especially goods and hindered commerce; they reflected British concerns about economic matters and their adhesion to liberalism, to which quarantine regulations were an anathema. For Crete in particular, the same 'reporter', Bowring, noted when recording the regularity of steamer communication between Egypt and European ports in the mid 1830s: "I understand that the calling at the Island of Crete is, or is about to be, abandoned; principally from the embarrassments caused by the quarantine regulations. ${ }^{\prime 39}$ In Egypt, commercial prosperity and security were promoted by the official newspaper in Egypt in order to attract more merchants. ${ }^{40}$ In Crete, even if the administration through the medium of its newspaper attempted to present the island as a secure environment for trade, quarantine delays probably demonstrated the opposite.

Although quarantine was enacted in Egypt and Alexandria for the prevention from disease, serious doubts had been expressed on its efficacy. The elaborate system of lazarettos, military cordons and quarantines developed in the Mediterranean was deleterious to trade, communication and the movement of people. The dispute between pro and anti quarantine regulations involved policymakers, state functionaries responsible for enforcing quarantine, merchants and commercial interests, and, of course, the medical profession. ${ }^{41}$ Both Bowring and Clot in Egypt were advocates for the abolition of quarantines. ${ }^{42}$ Clot conducted experiments and proved that disease was not communicable. ${ }^{43}$ Yet quarantines remained the standard measure taken by Mehmed Ali in Egypt, as well as by Mustafa Paşa in Crete because of the danger of plague outbreaks throughout the 'Levant': "From the $27^{\text {th }}$ October 1828 to the $17^{\text {th }}$ January 1837 ,

38. John Bowring, 1998, Report on Egypt, 1823-1838, under the reign of Mohamed Ali, London: Triade Exploration Ltd, p. 296.

39. Bowring, p. 194.

40. Juan R.I. Cole, 1993, Colonialism and Revolution in the Middle East: social and cultural origins of Egypt's 'Urabi movement, Princeton, N.J : Princeton University Press, pp. 118-132.

41. Kuhnke, p. 69.

42. Kuhnke, p. 75.

43. Kuhnke, p. 87. 
the plague constantly prevailed in the Levant. This was introduced by pilgrims arriving from the Turkish Levant." ${ }^{44}$

Debates on medical theories, different conceptualisations of disease and its aetiology, similar to those that took place in Europe and to some extent in Egypt, reverberated in Crete during the period of Egyptian rule in the form of theoretical recommendations and preventive practices; debates however did not take place in the newspaper pages. In Cairo, supporters of the miasmatic theory also suggested that the horrible odours were not compatible with a modern city, whose citizens were entitled to breathing fresh air. ${ }^{45}$ Medical practices and technologies introduced in Egypt, such as quarantine and smallpox vaccination, illustrate that Mehmed Ali adopted protective measures recommended by both contagionists and anti-contagionists, in the search for prestige and the verve to show bases of modernization of the country, but also in order to satisfy his European trading partners. ${ }^{46}$

The most important and perhaps most urgent task of the Egyptian administration was indeed to save the island from the plague. Crete, a regular destination of sailing ships from the Central and Eastern Mediterranean, was affected by periodic waves of the disease. For this reason, the administration, under Mehmed Ali's orders, devised a set of quarantine and other regulations, particularly detailed when it came to the ships that arrived in the island. The information coded for the knowledge of the authorities contained all previous ports of call and whether ships had called to areas infected or 'suspicious' of being infected with the plague. Equal attention was paid to the cargo and passengers and, if found suspect, everyone was placed in quarantine for different periods depending on the previous destinations of the ship. The detailed procedures included the fumigation of letters. It was the duty of the officials in sanitary stations to notice whether any of the quarantined passengers and crews got ill and to take the necessary measures. ${ }^{47}$ These strict guidelines demonstrate an organized system of prevention against the plague. From the contemporaries' point of view, the system must have looked efficient enough; during the 1830s there were no outbreaks of the disease in the island. ${ }^{48}$

\section{Bowring, p. 282.}

45. Khaled Fahmy, 'An olfactory tale of two cities: Cairo in the nineteenth century', in Jill Edwards (ed.), Historians in Cairo: Essays in Honor of George Scanlon, Cairo: American University in Cairo Press, 2002. This view is particularly interesting because of its complementarity to views on 'liberal governmentality' that shaped power relations in British, European and Colonial Cities and involved the concept of 'circulation' of people, water and air in a modern city; see, Patrick Joyce, The rule of freedom: liberalism and the modern city, London : Verso, 2003.

46. Kuhnke, p. 5.

47. VG, No. 16, 25/4/1831. 
Any consideration and implementation of quarantine and other sanitation measures involved complex issues such as international trade, the state of medical knowledge, as well as the ability of the state to implement quarantine measures. The orders given by the authorities in Crete were not adhered to, at least in the immediate first weeks. Soon after the proclamations for the establishment of a board of health and the quarantine regulations, new orders were issued alerting the population to the dangers of the smuggling trade for public health. The smuggling trade meant loss of revenue for the administration, as well as an increased danger of contagious diseases. In Chania, these efforts included tighter control on the port through reduction of its entry and exit points, and an increase in the number of guards of the Customs Office as well as their salary. ${ }^{49}$ Officers had to inform local residents and ask for their cooperation in convincing ship captains to go to the lazarettos for quarantine and obtain a clean bill of health. The authorities also ensured that the lazarettos were properly maintained and the buildings renovated for the comfortable stay of passengers, at least in one of the biggest lazarettos of the island in Chania. ${ }^{50}$ The administration of those offices was assigned to Christians as well as Muslims, in a practical application of the authorities' pronounced promotion of religious equality and equal opportunities for public office. ${ }^{51}$

No disease broke out in Crete during the period when the newspaper was published and therefore, we do not have an idea of the reactions such a crisis would have provoked; a real test for the island's scant but improving medical facilities. During the plague of 1835 in Egypt, however, when the epidemic threatened to decimate the naval personnel, the fleet from Alexandria was temporarily stationed in Crete for protection. ${ }^{52}$ Quarantine and other isolation measures were not always strictly upheld, not even by the navy. Dr Abbott, naval surgeon on Abu Qir, one of the largest vessels in the Egyptian navy, thought measures such as fumigation of letters were useless. When the fleet was sent from Alexandria to Crete he ignored the standard procedure of fumigation of supplies, blankets and woollen clothing and he even allowed the wives and relatives of sailors to bring blankets and clothes to the ship before it sailed for Crete. ${ }^{53}$ Another medical view by Koch, head of the navy medical staff, was

48. K. Kostis, 1995, Ston kairo tis Panolis. Eikones apo tis koinonies tis ellinikis hersonisou, 140s-19os aionas [In the times of Plague. Images societies of the Greek peninsula, 14 $4^{\text {th }}-19^{\text {th }}$ century], Panepistimiakes Ekdoseis Kritis, Athina, 410-11. According to Kostis, the plague appeared for the last time in Crete in 1821, brought by the Ottoman fleet.

49. VG, 1833, No. 88, 23 February.

50. VG, 1832, No. 81, 15 December.

51. VG, 1832, No. 82, 24 December.

52. Kuhnke, p. 83.

53. Kuhnke, p. 88. 
expressed in his letter to Clot; because strict quarantine regulations had been ignored, there were outbreaks among the sailors: "during the voyage to Crete and at Crete itself, in rigorous quarantine, several cases of plague broke out on board of different ships." ${ }^{54}$ Fortunately, the plague was not transmitted to Crete during the fleet's stationing there. Koch was ultimately dismissed for failing to obey Mehmed Ali's strict rules for observing quarantine regulations.

\section{TARGETING SMALLPOX: THE INTRODUCTION OF VACCINATION IN CRETE}

In the early $18^{\text {th }}$ century, the Royal Society in London was aware of smallpox inoculation practice in the Levant when Sherard, a Fellow of the Society, confirmed Timoni's account of inoculation from smallpox. Emmanuel Timoni had published the now famous treatise on smallpox and inoculation, which practically introduced the practice of inoculation in Western Europe. ${ }^{55}$ The impact of inoculation and subsequently vaccination in Western Europe, it has been argued, was enormous, since it not only prevented premature (in fact mainly child) deaths, but also infertility and other infections that smallpox can cause. ${ }^{56}$ Studies on India in the nineteenth century show extremely high smallpox fatality rates, between 20 and 50 percent. ${ }^{57}$ It would not be realistic to hunt for records of epidemiological data that could lead to similar statistical exercises and results for Crete during the 1830s. The data on India, nevertheless, provides a picture of how widespread and destructive the disease could be. Vaccination was brought to India from England after 1802. Until then, the only effective method had been inoculation. ${ }^{58} \mathrm{~A}$ full vaccination programme was not initiated in some provinces until 1867. If properly administered, the vaccination programme could reduce deaths from smallpox in a relatively short time. Still, vaccination did not become commonplace before the $1850 \mathrm{~s}$ and its impact was not felt in India until the 1880s and ultimately resulted in significant decline in mortality from smallpox.

We do not know the death rate from smallpox in Crete, but given the plan to introduce vaccination in the island it must have been quite significant,

54. Kuhnke, p. 88.

55. Raymond Phineas Stearns, 1954, 'Fellows of the Royal Society in North Africa and the Levant, 1662-1800', Notes and Records of the Royal Society of London, 11, 1, pp. 75-90.

56. Peter Razzell, 1977, The Conquest of Smallpox: The Impact of Inoculation on Smallpox Mortality in Eighteenth-Century Britain, Firle: Caliban Books.

57. Jayant Banthia, Tim Dyson, 1999. 'Smallpox in Nineteenth-Century India', Population and Development Review, 25, 4, pp. 649-680.

58. Jayant Banthia, Tim Dyson. 'Smallpox in Nineteenth-Century India', p. 659. 
although perhaps not as significant and widespread as the plague. There is plenty of evidence that inoculation was widely practiced as early as the seventeenth and eighteenth century in the rest of Africa but its demographic impact is extremely hard to estimate even in approximation. ${ }^{59}$ In Crete, there is no evidence that any sort of inoculation was practiced in the island before vaccination with cowpox (in the 1830s), but perhaps the ancient practice of variolation with scabs or pus had been practiced in the island as in other places in the Mediterranean and the Balkans.

Dr. Clot had identified smallpox as the principal cause of child mortality since his arrival in Egypt. ${ }^{60}$ The French physician also claimed that the introduction of immunization in Egypt in 1827 was his personal achievement. According to the Vekayi-i Giridiye, Mehmed Ali himself ordered the smallpox vaccine to be brought to Crete from Europe and provided it to infants for free. The article in the newspaper announced the intention and pledge of the administration to bring from Europe "or from wherever else he may prefer" vaccination against smallpox. The residents of the island would be informed to bring their children for vaccination or a local official would visit them to carry out the order. ${ }^{61}$ It is interesting to note that measures against the plague and smallpox were simultaneously announced. The two diseases constituted probably the two major dangers to public health in Crete and the Egyptian administration attempted to tackle them in the first months after taking over officially in Crete.

What was novel for the island's population was immunization with the cowpox vaccine. Vaccines were distributed for free to both Christian and Muslim infants in an exemplary demonstration of community equality in public health measures. The administration was mature enough to acknowledge that any disease outbreak would not discriminate between Christians and Muslims and could easily escalate into an epidemic. Previous attempts to introduce vaccination in the island had apparently failed because they lacked precisely the official promotion and organization by the state that was promised in the newspaper issue of April 1831. ${ }^{62}$ Vaccination against small pox soon became a priority of the authorities. In 1832, substantial quantities of vaccine were brought for vaccination, in order, as it was specifically stated, "to protect the Muslim and Christian children of Crete from smallpox death." As the Chief Medical Inspector Caporal proclaimed in the same issue, it had

59. Eugenia W. Herbert, 1975, 'Smallpox Inoculation in Africa', The Journal of African History, Vol. 16, No. 4., pp. 539-559.

60. Kuhnke, 112.

61. VG, 1831, No. 16, 25 April.

62. Sieber mentions that one of his guides in the island in 1817, named Giorgis, had brought the vaccine in previous years "and saved many thousands of children from the deadly smallpox that ravaged these places." Sieber, p. 217. 
proven difficult to acquire all the necessary quantities of the vaccine from Istanbul, Izmir or Syros, and so he turned to the French Consul in Crete, who in turn intervened; adequate quantities of the vaccine were brought from France. For this reason, the Caporal publicly stated his gratitude to the French authorities in the official newspaper. ${ }^{63}$

All men serving in the Egyptian army were vaccinated and, if sick, had access to some proper medical facilities and expertise, a favourable treatment when compared to the rest of the population. In the long run and for the wider population, the vaccination programme, although not comprehensive, certainly improved Egyptians' health. The same could be said about Crete. Given though that no men were conscripted from Crete, medical facilities in the island were primarily created for the army stationed there. It is true that the naval hospital in Alexandria treated not only the army staff but also Arsenal employees as well as seamen. ${ }^{64}$ We can only speculate on the extent to which these facilities were used by patients among the local population of Crete. Health care in schools was also promoted in Egypt; in Crete, the only sanitary measure that was taken - significant nevertheless - was the construction of new schools in areas with healthy conditions, namely clean and healthy air. ${ }^{65}$ How were these health measures received? Pashley notes the serious reservations expressed by 'Greeks' about the sincerity of the proclamations for the building of two schools in Crete; he mentions that Christians considered it a pretext for gathering the children for conscription and sending them to Egypt. ${ }^{66}$ The traveller's account paints a very different picture of how innovations that seem, and may well have been, benevolent were perceived by the local population as means of asserting power over them. A census and control of 'unhealthy' and 'impolite' activities such as prostitution, for instance, increased surveillance and had a coercive dimension as well as a humanitarian one.

\section{CONCLUDING COMMENTS}

In the concluding chapter of her book on public health in nineteenth-century Egypt, Laverne Kuhnke asks: "Were the medical institutions and technologies introduced by Mehmed Ali adaptable to local circumstances or did their Western origins make them inappropriate for Egypt?" ${ }^{67}$ We ask a similar question regarding the institutions and practices of public health in Crete during the period of Egyptian rule, in the 1830s. The religious diversity of the population

63. VG, No. 70, 29 August, 1832.

64. Kuhnke, 136.

65. VG, No 104, 11 August, 1833.

66. Pashley, xxxiii.

67. Kuhnke, p. 153. 
(Christians, Muslims and a few hundred Jews); the administration structure of the island during the 1830s; as well as the fact that institutions and practices introduced were filtered through their initial application in Egypt, made the adaptation of medical institutions and technologies all the more debatable. At the same time, these factors make the case of Crete under Egyptian rule all the more interesting. This is because we have the opportunity to investigate how Mehmed Ali's state, which received western medical institutions, ideas and technologies, attempted to transfer them to Crete. This process allows us also - albeit tentatively - to speculate on the form of Egyptian rule in Crete and its character, namely whether and to what extent it resembled a colonial-style administration. ${ }^{68}$

The paper demonstrated some of the ways in which the modernising model of Mehmed Ali, although undoubtedly influenced by French practices and ideas, constituted essentially a means of establishing and consolidating Egyptian power in Crete. These practices were not transferred to Crete from France unmediated. On the contrary, the Egyptian 'filtering' was extremely important, and the changes introduced to Crete were advertised as OttomanEgyptian and not as French or European. This process emanated from the centralised state of Mehmed Ali and was implemented by local representatives of Egyptian power in Crete, some of whom were Europeans. The detailed information provided in the newspaper Vekayi-i Giridiye shows that reforms aimed at establishing the necessary conditions for a better administrative practice, regardless of religion. To this end the authorities consulted village councils and notables, both Christian and Muslim, although there is little evidence that consultation had any impact on decision-making. The modernising project certainly promoted social welfare and was indeed portrayed to have done so; we argue, nevertheless, that this was not its only or even its primary aim. Modernising reforms in Crete legitimised the Egyptian rule and in the case of a modern and efficient health system, benevolence aimed perhaps at gaining popular support, as well as serving military needs by maintaining soldiers' good health.

The issue of Egyptian rule in Crete is far too complex to be tackled here, in a paper focused on public health. In Crete the mixed - in terms of religion - population received medical innovation from a new source of authority (the Egyptian Viceroy) but within the context of the old authority (Ottoman). While there are ongoing serious debates as to the nature and character of Mehmed Ali's regime (Egyptian or a hybrid Ottoman-Egyptian), into which we cannot afford to enter and which is part of the wider discussion on the relationship between Europe, the Ottoman Empire and Egyptian nation-building, suffice

68. For the debate between 'nationalists', who see Mehmed Ali as the founder of Modern Egypt and opponents, see, Khalid Fahmy, 1997, All the Pasha's Men: Mehmed Ali, His Army and the Making of Modern Egypt, New York : Cambridge University Press. 
it to say here that any examination of Crete during the 1830s will have to confront similar questions and specifically the nature of Egyptian rule of the island, i.e., whether it represented a form of colonial rule and what was the role of colonial medicine in such a context. We tend to think that in Crete quarantine regulations, vaccination and other health and hygiene measures rather strengthened the rule of the Egyptian regime, essentially a rule of law, as well as force. Looking at issues of public health is a particularly pertinent way of looking at the issue of the form Egyptian rule assumed in Crete, since any introduction of new medical measures and their reception raises questions of power and inter-community relations between the island's Christian and Muslim populations. The willingness to introduce measures against the spread of disease demonstrates the attempt to move territories under the rule of Mehmed Ali further from Ottoman 'backwardness' and closer to Europeaninfluenced 'modernising' practices.

If we had to summarise the importance of innovation and modernisation introduced in Crete during the period of Egyptian rule, we would argue that its significance lies in the fact that this 'modernization process' was adopted in later periods and in other regions of the Ottoman Empire during the Tanzîmât period. After 1861, when Midhat Paşa, one of the principal reformers of Tanzîmât, was appointed governor of the Tuna Vilayeti in the Danube, he introduced a modernising programme similar to the one followed by Mehmed Ali in Crete. This programme included public works, agricultural reform, incorporation of Christian and Muslim councils in the local administration, public education reforms, judicial reforms and the publication of the bilingual newspaper Tuna (Danube) in Ottoman and Bulgarian. A similar reform programme was attempted by Midhat Paşa in Iraq when, a few years later, he was appointed governor of Baghdad; the bilingual newspaper Zevrâ was published there in Ottoman and Arabic. The model of regional administration adopted by Midhat Paşa was to a certain extent influenced by that of Mehmed Ali in Crete. It could be argued that the implementation of the reform programme in Crete during the period 1830-1840 served to some extent as a prelude and a model for establishing similar reforms in other places in the Ottoman Empire. Reforms, undertaken in Crete in the Ottoman 'periphery' by the Egyptian administration, were later followed and spread to other parts of the same 'periphery'.

Any account of health reforms and early attempts to devise a social policy during the period of Egyptian rule in Crete, which is limited to the data presented by the official newspaper is bound to be one-dimensional and conceal perhaps as much as it reveals about this - still - blind spot of Mediterranean history. This paper attempted to extract all the information that concerned changes in public health in Crete, focusing on the building of health infrastructure and fighting the main hazards that contemporaries perceived as the gravest threat: plague and smallpox. These were no small tasks. In direct relation to the changes introduced by Dr. Clot in Egypt, Egyptian authorities in 
Crete established a system of quarantines, health stations and hospitals, primarily for the protection of the army stationed there. Most important for the local population, they promoted vaccination against smallpox. Whether this reform was as effective in Crete as it was in Egypt cannot possibly be answered in this paper. Still, some interesting aspects of public health reform in Crete, a region under Egyptian rule, have been identified and future research aided by sources other than the official newspaper will hopefully provide alternative vantage points on how these changes were perceived by the local population, Christian as well as Muslim.

\section{WORKS CITED}

BANTHIA Jayant, Tim Dyson, 1999, 'Smallpox in Nineteenth-Century India', Population and Development Review, 25, 4, pp. 649-680.

BowRING John, 1998, Report on Egypt, 1823-1838, under the reign of Mohamed Ali, London, Triade Exploration Ltd, p. 296.

Cole Juan R.I., 1993, Colonialism and Revolution in the Middle East: Social and Cultural Origins of Egypt's 'Urabi Movement, Princeton, N.J : Princeton University Press, pp. 118-132.

Faнmy Khaled, 2002, 'An olfactory tale of two cities: Cairo in the nineteenth century', in Jill Edwards (ed.), Historians in Cairo: Essays in Honor of George Scanlon, Cairo, American University in Cairo Press.

FaHmy Khalid, 1997, All the Pasha's Men: Mehmed Ali, His Army and the Making of Modern Egypt, New York, Cambridge University Press.

Herbert Eugenia W., 1975, 'Smallpox Inoculation in Africa', The Journal of African History, Vol. 16, n4., pp. 539-559.

JorCe Patrick, 2003, The Rule of Freedom: Liberalism and the Modern City, London, Verso.

KunnKe, LaVerne, 1990, Lives at Risk: Public Health in Nineteenth-Century Egypt, Berkeley, University of California Press, p. 35.

Kostis K., 1995, Ston kairo tis Panolis. Eikones apo tis koinonies tis ellinikis hersonisou, 14os-19os aionas [In the times of Plague. Images societies of the Greek peninsula, $14^{\text {th }}-19^{\text {th }}$ century], Panepistimiakes Ekdoseis Kritis, Athina, 410-11.

Moulın Anne Marie, 2002, "L'esprit et la lettre de la modernité égyptienne. L'enseignement médical de Clot bey », Cahier des Annales islamologiques, 22, pp.119-134.

Pashley Robert, 1837, Travels in Crete, Vol. 1, Cambridge \& London, John Murray, p. XXII.

Razzell Peter, 1977, The Conquest of Smallpox: The Impact of Inoculation on Smallpox Mortality in Eighteenth-Century Britain, Firle, Caliban Books.

SieBER F.W., 1823, Travels in the Island of Crete, in the Year 1817, London (Greek translation, Athens, Istoritis, 1994). 
Stearns Raymond Phineas, 1954, 'Fellows of the Royal Society in North Africa and the Levant, 1662-1800', Notes and Records of the Royal Society of London, 11, 1, pp. 75-90.

WAtTs Sheldon, 1997, Epidemics and History. Disease, Power and Imperialism, New Haven \& London, Yale University Press. 